1984

\title{
Oregon Donation Act of 1850 and Nineteenth Century Federal Married Women's Property Law, The
}

Richard H. Chused

New YorkLaw School, richard.chused@nyls.edu

Follow this and additional works at: http://digitalcommons.nyls.edu/fac_articles_chapters

\section{Recommended Citation}

2 Law \& Hist. Rev. 44 (1984)

This Article is brought to you for free and open access by the Faculty Scholarship at DigitalCommons@NYLS. It has been accepted for inclusion in Articles \& Chapters by an authorized administrator of DigitalCommons@NYLS. 


\title{
The Oregon Donation Act of 1850 and Nineteenth Century Federal Married Women's Property Law
}

\author{
Richard H. Chused
}

\begin{abstract}
Almost every state and territory adopted a married women's property act between 1835 and 1850 . These acts generally exempted married women's property from attachment by creditors of their husbands, effecting a slight change in the battery of common-law coverture rules that gave husbands management of their wives' real property and ownership of their personal property. Alterations in the roles of women in the family, increases in education of women and growth in the importance of women's public service groups provided an environment sympathetic to initial reforms in married women's property law. In addition, economic panics and depressions affected the family economy, providing an incentive for adoption of rules exempting married women's property from the claims of their husbands' creditors.'

Despite the widespread adoption of married women's acts by state legislatures, the mass of federal land grant statutes passed before 1850 generally displayed none of the characteristics of state married women's acts. Save for the Oregon Donation Act of $1850,{ }^{2}$ married women were never designated as statutory takers of federal land patents; no land grant act ever exempted married women's property from the debts of husbands.
\end{abstract}

Richard H. Chused is Associate Professor of Law, Georgetown University Law Center. 1 would like to extend my thanks: David Zolensky, J.D. 1982, Georgetown University Law Center, did a great deal of sleuthing while serving as my research assistant during the 1980-1981 academic year. James R. Perry, coeditor of the Documentary History of the Supreme Court of the United States, 1789-1800, transcribed the difficult handwriting of Samuel R. Thurston, making his letters usable for this project. James H. Miller, J.D. 1982, Lewis \& Clark Law School, served as my research assistant at the Oregon Historical Society during the 1980-1981 academic year. Renee M. Jaussaud of the National Archives spent many hours with me looking for Oregon Donation Act records. Professors Wendy W. Williams and Mark Tushnet of Georgetown University Law Center read and commented on drafts of the article, as did James Perry, Maeva Marcus, also coeditor of the Documentary History of the Supreme Court project, Jamil Zainaldin, of the American Historical Association, Lloyd Bonfield of Tulane Law School and William Nelson of New York University Law School. Dean David J. McCarthy was very generous in providing funds for research assistants and other needs. Terry Martin, the Georgetown law librarian until 1982, and Robert Oakley, our present librarian, and the library staff have been very helpful in obtaining materials.

1. On the adoption of state married women's property acts, see Richard H. Chused, 'Married Women's Property Law: 1800-1850,' 71 Georgetown Law Journal 1359 (1983).

2. 9 Stat. 496 (1950).

๑Richard H. Chused, 1984 
The federal government's failure to legislate in areas affecting women reflected a general consensus that regulation of families, privately owned land, and debtor-creditor relations were state concerns. Local legislatures routinely exempted a variety of assets, including tools, furniture, household necessaries, and married women's property from creditor access, while Congress usually stayed its hand. When Congress did intervene, the legislation was short-lived or motivated by different concerns. For example, Congress's adoption of bankruptcy laws in 1800 and 1841 occurred amidst great controversy, and both acts were quickly repealed. ${ }^{3}$ Alterations in general land grant practice during the first half of the century to permit some women, particularly widows and female heads of families, to obtain federal land patents, were designed to perfect the claims of deceased men rather than to recognize cultural changes in the nature of the American family, the education of women or the growth of women's public service groups.

The Oregon Donation Act is therefore an unusual piece of land grant legislation. Although it was passed near the end of the period in which most states adopted their first married women's acts, the dearth of any other federal legislation displaying an inclination towards reform of married women's property law renders it unlikely that the Oregon Donation Act merely reflected the influence of the nineteenth-century women's property reform movement. Indeed, available evidence suggests that a number of forces, some quite unusual, merged to cause the adoption of Oregon's land bill. In addition to the married women's acts, Congress was influenced by the perceived need to attract women to a distant territory, the near adoption of land bills in prior Congresses providing for larger grants to married than to single men in Oregon, the actions of settlers in Oregon who had established a provisional government to distribute possessory land interests while the area was without a sovereign authority, the slow growth of a national free land or homestead movement, the presence of an Oregon Territorial delegate sympathetic to women's law reform, and the dire need for land legislation in a newly acquired territory.

The purpose of this paper is to explore the relationship between federal land legislation and women's property rights. Although it is clear that Congress perceived married women's property law to be a matter of primarily local concern, federal interest in married women during the nineteenth century has never been discussed. Despite the unusual qualities of the Donation Act, the controversy surrounding its adoption sheds light on both the nature of the state married women's law reform movement and the different purposes served by state and federal legislation. Moreover, the adoption of the Donation Act by Congress at the behest of Samuel R. Thurston, Oregon's territorial delegate, provides insight into the roots of women's law reform in traditional male circles during the middle of the nineteenth century. The multitude of forces present in Congress when the

3. See Peter J. Coleman, Debtors and Creditors in America: Insolvency, Imprisonment for Debt, and Bankruptcy, 1607-1900 (Madison, 1974) 16-36. 
Donation Act was enacted provided a brief but important moment during which the married women's law reform movement affected the development of federal law. To place Oregon's experience in context it is useful to commence with a survey of early federal land grant policy.

\section{I}

Acquisition and distribution of land was a vital concern of early Congresses. ${ }^{4}$ The cession of the western territories to the central government, the sale of land to raise money for government use, the granting of land to soldiers of the Revolutionary War, and the confirmation of land titles of settlers and supporters of the revolution against British rules were debated. ${ }^{5}$ Although the Land Ordinance of $1785^{6}$ provided for the sale of public lands by auction, the grant of land to soldiers, and the surveying of the territories, the disposition of the newly acquired public domain was significantly delayed by lingering conflicts with the British and the Indians. ${ }^{7}$

Nonetheless, some land was distributed and people began to move to the Northwest Territories. A system for organizing governments and resolving land disputes had to be established. The Northwest Ordinance of 1787 was the basic legislative model for organizing most territories east of the Mississippi River. ${ }^{8}$ In conformity with the general practice of the day, it provided for male-dominated territorial governments. ${ }^{9}$ But the ordinance also contained several family law reform measures which substituted intestate succession by all children in equal parts for primogeniture, saved in all cases to the widow of the intestate her third part of the real estate for life, and one third part of the personal estate,' and granted women the rights to write wills and to transfer their interest in land by lease and release or bargain and sale. ${ }^{10}$ These measures were similar to statutes adopted in many

4. The Continental Congress passed several resolutions urging the states to cede their western territories to the central government as a capital resource vital to the payment of the nation's creditors. See, e.g., the consideration of a cession resolution of April 29 , 1784, Journals of Continental Congress 26 (April 29, 1784) 315-17.

5. Paul W. Gates, History of Public Land Law Development (Washington, D.C., 1968) 49-119.

6. An Ordinance for Ascertaining the Mode of Disposing of Lands in the Western Territory, Journals of Continental Congress 28 (May 20, 1785) 375-81.

7. Gates, Public Land Law, supra note 5, 59-61, 69-72.

8. An Ordinance for the Government of the Territory of the United States North West of the River Ohio, Journals of Continental Congress 32 (July 13, 1787) 334. The Act was extended to the Kentucky and Tennessee Territories in the Southwest Ordinance, An Act for the Government of the Territory of the United States, South of the River Ohio, 1 Stat. 123 (1790), and to the Mississippi Territory, in An Act Supplemental to the Act Entitled 'An Act for an Amicable Settlement of Limits With the State of Georgia; and Authorizing the Establishment of a Government in The Mississippi Territory,' 2 Stat. 69 (1800).

9. Males holding a freehold of fifty acres or more could vote. Journals of Continental Congress 32 (July 13, 1787) 334, 337-38.

10. Ibid. 334-35. 
states before 1800.1' Removing burdens on transfer of land was of concern well before the Revolution. The blossoming of romantic mate selection, the increasing responsibilities of women in the home and the growth of special norms for the rearing and education of children gave impetus to the alteration of family inheritance regimes in the late eighteenth century. ${ }^{12}$

Though peppered with private law provisions, the Northwest Ordinance did not intrude far into areas perceived as local concerns. All property law provisions were temporary, lasting until territorial legislatures were constituted and adopted measures of their own. Despite the creation of a federal land sale bureaucracy, local rather than federal property law governed the control of federal lands after they were conveyed to private parties. A precedent was therefore set for limited federal intervention in family, property and other 'local' matters. Until the adoption of the Oregon Donation Act, property disposition systems adopted after the Northwest Ordinance followed the same tradition.

A complex system developed to dispose of the millions of acres in the public domain. Prior to 1815 , federal lands were usually sold through private land companies; thereafter a federal bureacracy with offices distributed around the frontier was organized to dispose of federal property. ${ }^{13}$ Until 1841 , newly surveyed land could be purchased only after a public auction was held, except for the lands covered by a series of limited preemption acts. Even though these acts grew progressively broader in their coverage, the early land situation left most large agricultural land purchases in the hands of land companies and speculators.

Most recipients of federal land before 1830 were men. ${ }^{14}$ Nonetheless, there are indications that widows and female heads of families were

11. See Chused, 'Married Women's Property Law,' supra note 1, 1392-95, 1404-5.

12. Ibid. 1414-19.

13. See Gates, Public Land Law, supra note 5, 121-27. An Act Providing for the Sale of the Lands of the United States, in the Territory Northwest of the River Ohio, and Above the Mouth of the Kentucky River, I Stat. 464 (1796). The Land Act of 1796 established the Office of Surveyor General, and began the establishment of a sales bureaucracy in the territories. Land offices were called for explicitly by acts adopted in 1800 and 1804. Both of these acts also reduced the size of plots open for purchase to try to increase sales. An Act to Amend the Act Intituled 'An Act Providing for the Sale of the Lands of the United States in the Territory Northwest of the River Ohio, and Above the Mouth of the Kentucky River,' 2 Stat. 73 (1800); An Act Making Provision for the Disposal of the Public Lands in the Indiana Territory, and for Other Purposes, 2 Stat. 277 (1804). The General Land Office was established in 1812. An Act For the Establishment of a General Land Office in the Department of the Treasury, 2 Stat. 716 (1812).

14. Absent a look at the huge collection of records at the National Archives, it is not possible to provide definitive data on the gender of land purchasers. But some other materials are available which provide very strong evidence of the early patterns. Some congressional reports included lists of land claimants, providing a convenient, though crude, way to review the participation rates of women. Among the reports are four scattered over about a thirty-five year period from 1811 on. Settlers on Public Lands, H.R. Doc. No. 182, 11th Cong., 3d Sess. (1811); Sundry Statements of the Commissioner of the General Land Office, of the Quantity of Land Sold Under the Provisions of the Act of 
emerging as a problem for the land disposition system. Numerous claims were made by persons tracing their titles to sovereigns controlling portions of the Northwest Territory before they came to be possessions of the United States. ${ }^{15}$ In some cases, husbands had died in the intervening years. In an early attempt to settle such private land claims, the Continental Congress donated 400 acres to settlers who were heads of families, including women. ${ }^{16}$ The practice continued with later acts of Congress. ${ }^{17}$ Similarly, widows and heirs of Revolutionary War refugees and soldiers were the subject of legislative activity as early as 1783 , with attempts to notify potential claimants continuing for some time. The potential claimants were heads of families, single persons, and widows and heirs. ${ }^{18}$

Although federal statutes began to consider the welfare of family members associated with males who were the recipients of national largesse, the steps to protect women were very limited. Only if women were part of a family whose male head was dead but still the object of national thanks, were federal benefits generally available. Widows of actual purchasers of land were left largely to the whims of state or territorial law which frequently

the 24th April, 1820, H.R. Doc. No. 35, 16th Cong., 2d Sess. (1820); Sale of Lands in the First District of Louisiana, H.R. Doc. No. 113, 21st Cong., 2d Sess. (1830); List of Purchasers of Land at Columbus and Chocchuma in Mississippi in 1833 and 1834, S. Doc. 1263, 23d Cong., 2d Sess. (1834). The 1811 report dealt with applicants under a statute permitting settlers to occupy land as tenants at will until it was later distributed. Only eight of the 407 plots involved applicants who were clearly women. Four others may have been women. (They had names like Francis.) Of the 953 parcels in the 1820 report, only eight were clearly purchased by women. Three others were possibles. The 1820 act was a reform of the nationally applicable land sale laws. Of the seventy-three parcels in the 1830 report, five were purchased by a woman named Mrs. Constance Duneufbourg. The 1834 report contains so many entries it wasn't worth counting. A quick scan revealed very few women. And, of course, no information on marital status was available in these reports. Moreover, Albion Morris Dyer, First Owners of Ohio Lands (Boston, 1911) includes a list of purchasers at the first New York land sale under the Land Ordinance of 1785 that contained no women. Dyer also found a list of the Ohio Company proprietors, three percent of whom were women. The proprietors owned shares in the company, rather than land on the frontier.

15. Gates, Public Land Law, supra note 5, 87-92.

16. Journals of Continental Congress 34 (June 30, 1788) 247.

17. See, e.g., An Act for Granting Lands to the Inhabitants and Settlers at Vincennes and Illinois Country, in the Territory Northwest of the Ohio, and For Confirming Them in Their Possessions, I Stat. 221 (1791).

18. An Act for the Relief of the Refugees From the British Provinces of Canada and Nova Scotia, 1 Stat. 547 (1798). Sec. 2, 1 Stat. 548. Inevitably there were disputes over the disposition of rights in bounty lands and land warrants held by surviving wives. See, e.g., 1 Op. Atty. Gen. 311 (1819); Gales \& Seaton, General Public Acts of Congress Respecting the Sale and Disposition of the Public Lands, with Instructions Issued, From Time to Time, By the Secretary of the Treasury and Commissioners of the General Land Office and Official Opinions of the Attorney General on Questions Arising Under the Land Laws, 2 vols. [hereafter Gales \& Seaton] (1838) i, 418-19; 2 Op. Atty. Gen. 579 (1833). The Attorney General opinions involve application of state law of succession to rights in federal land held by widows. 
limited their rights. ${ }^{19}$ Thus, just before states began adopting married women's acts, federal statutes displayed very little evidence that Congress was moving in a similar direction. While many family law and debtor protection precursors to married women's acts were adopted by states before $1830,{ }^{20}$ Congress protected women only to establish titles in the families of men who died with valid claims to federal land or to protect the families of certain men who had served the republic during its formative years.

\section{II}

In addition to the problem of succession by widows to granted lands, early nineteenth-century Congresses were bedeviled by the claims of persons who had settled on the public domain before their land was officially opened for auction and sale. Some of the squatters were opportunists and speculators, some were takers from prior sovereigns, and some were longtime settlers who had opened the frontier for agricultural development. Despite the complexity of validating squatters' claims to land traditionally open for sale to the public, Congress began adopting 'preemption' acts giving settlers the right to purchase their claims prior to open auctions or sales. Pressure also built for the distribution of free land. Public criticism of Congress's reliance upon land sales as a principal source of money for federal coffers mounted. Concern over land speculation, populist antipathy to banks and creditors, and demands from western settlers fueled the movement. By the middle of the century, Congress was willing to distribute free land as an incentive to draw people to sparsely settled territorries, such as Oregon. And, of course, the movement culminated with the adoption of the Homestead Act in 1862.

While some early preemption acts really resolved private land claims resulting from sovereignty changes, ${ }^{21}$ others were designed to correct problems caused by surveying errors, ${ }^{22}$ or to adjust claims in light of delays

19. See, e.g., Gales \& Seaton, supra note 18 , ii, 418 . This administrative dispute involved the wid ow of a man who had an unperfected right to land. His rights were left to his heirs under state law; the widow could not claim his rights unless she was his heir.

20. In addition to debtor protection legislation, states modified probate laws, abolished imprisonment of women for debt, enacted statutes providing somewhat greater protections for widows and deserted spouses and liberalized divorce laws. Chused, 'Married Women's Property Law,' supra note 1, 1404-9.

21. See e.g., An Act Regulating the Grants of Land, and Providing for the Disposal of the Lands of the United States, South of the State of Tennessee, 2 Stat. 229 (1803); An Act Providing for the Final Adjustment of Claims to Lands, and for the Sale of the Public Lands in the Territories of Orleans and Louisiana, 2 Stat. 662 (1811).

22. See, e.g., An Act to Authorize the Sale of Certain Lands Between the Great and Little Miami Rivers in the Territory of the United States Northwest of the Ohio; and for Giving a Preemption of Certain Purchasers and Settlers, 1 Stat. 728 (1799). Language used to designate takers was the gender-neutral 'persons.' 
in opening territories for settlement. ${ }^{23}$ Congressional debates on preemption were frequent and lengthy. Numerous preemption bills were adopted between 1800 and $1830 .{ }^{24}$ Finally, in 1830, the first preemption act applicable to settlers on all public lands was adopted. ${ }^{25}$ Very little administrative or judicial material on these early acts was published. ${ }^{26}$ What is available suggests how the early preemption system was used.

Perhaps the most interesting of available materials are those on the 1830 preemption act. ${ }^{27}$ It appears that the 'settler or occupant' language used in the statute to describe persons eligible to preempt included female heads of families. ${ }^{28}$ In one letter, the commissioner of the General Land Office instructed a register at a local land office that if a cultivator died during 1829 but his children, widow or other family members continued to occupy the land until the passage of the preemption act, then the preemption rights

23. See, e.g., An Act Giving the Right of Preemption in the Purchase of Lands to Certain Settlers in the Illinois Territory, 2 Stat. 797 (1813). This act was later extended to Florida, An Act Giving the Right of Preemption, in the Purchase of Lands, to Certain Settlers in the States of Alabama, Mississippi and Territory of Florida, 4 Stat. 154 (1826), and Missouri, An Act for the Final Adjustment of Land Titles in the State of Louisiana and Territory of Missouri, 3 Stat. 121 (1814).

24. A list may be found as a note to the Preemption Act of 1830, 4 Stat. 420 (1830). For a general review of these statutes see Gates, Public Land Law, supra note 5, 219-47. Statutes permitting settlers to squat as tenants at will, subject to removal on demand, were also adopted as compromise measures. See, e.g., An Act Relating to Settlers on the Lands of the United States, 3 Stat. 260 (1816).

25. An Act to Grant Preemption Rights to Settlers on the Public Land, 4 Stat. 420 (1830). This act permitted settlers to enter and purchase their claims for up to 160 acres if they had possessed and cultivated their land during the year 1829.

26. Reports of administrative actions of the early land bureaucracy are scarce. Some of the materials were compiled from time to time. Gales \& Seaton, supra note 18; W.W. Lester, Decisions of The Interior Department in Public Land Cases, and Land Laws Passed by the Congress of the United States; Together with the Regulations of the General Land Office, 2 vols. (Philadelphia, vol. 1, 1860; vol. 2, 1870); Henry N. Copp, Public Land Laws From 1869-1875 (Washington, D.C., 1875); Henry N. Copp, Public Land Laws From 1875-1882 (Washington, D.C., 1883). A reporting service called Copps's Land Owner was also published from 1874 to 1889. The National Archives also has materials, some of which have been used here. I have not looked at land title records.

27. For general background material see 3 Op. Atty. Gen. 126 (1836); 2 Op. Atty. Gen. 182 (1837); 3 Op. Atty. Gen. 309 (1838).

28. Prior to 1838 , the language used by Congress in the various preemption acts varied considerably. Some of the acts spoke only of 'people' or 'persons'as claimants. An Act to Authorize the Sale of Certain Lands between the Great and Little Miami Rivers in the Territory of the United States Northwest of the Ohio; and for Giving a Preemption to Certain Purchasers and Settlers, 1 Stat. 728 (1799); An Act to Authorize the State of Tennessee to Issue Grants and Perfect Titles to Certain Lands Therein Described, and to Settle Claims to the Vacant and Unappropriated Lands Within the Same, 2 Stat. 381 (1806); An Act Respecting the Claims to Land in the Indiana Territory and State of Ohio, 2 Stat. 395 (1806); An Act Providing for the Final Adjustment of Claims to Lands, and for the Sale of the Public Lands in the Territories of Orleans and Louisiana, 2 Stat. 662 (1811). Others referred to 'persons or legal representatives'-An Act Giving the Right of Preemption in the Purchase of Lands to Certain Settlers in the Illinois 
would 'inure to the head or representative of the family or person having the maintenance thereof.' 29 Just a few months later another letter went out instructing a register that a widow's remarriage did not destroy preemption rights accruing to her after the death of her first husband and that the preemption rights belonged to her, not her husband. The act, the commissioner wrote, 'says nothing of "legal representatives". 30 'Head of family' ideas were most certainly part of the underlying notion of settler or occupant. ${ }^{31}$ But a widow's rights were subject to serious limits. While she could continue possession after her husband's death and be treated as a settler on the effective date of the preemption act, the heirs (rather than the widow alone as head of the family) would take the patent if the husband died in possession after the effective date of the preemption act. ${ }^{32}$

By the end of the decade, the preemption acts began to reflect administrative practice more directly. ${ }^{33}$ The 1838 statute ${ }^{34}$ revived the 1830 act and absorbed most of the prior bureaucratic vocabulary by redefining the class of beneficiaries as 'every actual settler of the public lands, being the head of a family, or over twenty one years of age, who was in possession and a housekeeper, by personal residence thereon, at the time of the passage of

Territory, 2 Stat. 797 (1813); An Act for the Final Adjustment of Land Titles in the State of Louisiana and Territory of Missouri, 3 Stat. 121 (1814); An Act Concerning Preemption Rights in the Territory of Arkansas, 4 Stat. 39 (1824)-or to a 'person' or 'legal representative' of a person, who was the 'head of a family' or 'twenty one years of age.' An Act Regulating the Grants of Land, and Providing for the Disposal of the Lands of the United States, South of the State of Tennessee, 2 Stat. 229 (1803); An Act Supplemental to 'An Act Regulating the Grants of Land in the Territory of Michigan,' 2 Stat. 502 (1808); An Act Giving the Right of Preemption, in the Purchase of Lands, to Certain Settlers in the States of Alabama, Mississippi, and the Territory of Florida, 4 Stat. 154 (1826).

29. Gales \& Seaton, supra note 18, ii, 548-49. The letter was dated February 17, 1831.

30. Ibid. 557-58. The letter was dated September 8, 1831.

31. This is made explicit by 3 Op. Atty. Gen. 182, 184 (1837).

32. Gales \& Seaton, supra note 18, ii, 582 (Letter of October 23, 1833, from the Commissioner to a Receiver); Johnson v. Collins, 12 Ala. 322 (1847).

33. During the 1830 's, some statutes continued to use the terms 'settler or occupant.' See e.g., An Act Supplemental to the Act 'Granting the Right of Pre-emption to Settlers on the Public Lands,' 4 Stat. 603 (1832); An Act to Revive the Act Entitled An Act Supplementary to the Several Laws for the Sale of Public Lands, 4 Stat. 663 (1833); An Act to Revive the Act Entitled 'An Act to Grant Preemption Rights to Settlers on the Public Lands,' 4 Stat. 678 (1834). Another used the words 'settlers' and 'homemakers.' An Act Supplementary to the Several Laws for the Sale of Public Lands, 4 Stat. 503 (1832). The potential for women to be claimants under this act was confirmed by the Circulars to Registers and Receivers of the United States Land Offices by the General Land Office of May 8, 1832 and May 17, 1833. Report From the Secretary of Treasury in Compliance With a Resolution of the Senate of the 13th Instant, Transmitting Copies of the Instructions to the Receivers of Land Offices, in Relation to Preemption Rights and Other Unlocated Claims to Public Lands, S. Doc. No. 37, 25th Cong., 2d Sess., 18-21, 24-25 (1837). [Hereafter cited as Treasury Report of 1837].

34. An Act to Grant Preemption Rights to Settlers on the Public Lands, 5 Stat. 251 (1838). 
this act and for four months next preceding. ${ }^{35}$ In 1841 , Congress finally enacted a permanent ${ }^{36}$ preemption act. The statute provided that eligible claimants were persons 'being the heads of a family, or widow, or single man, over the age of twenty-one years. ${ }^{37}$ This act was modified two years later so that the death of a claimant prior to consummation of a land claim resulted in the issuance of a patent in the names of 'the heirs' of the deceased person. ${ }^{38}$ The contemporaneous administrative materials reflect the apparently well accepted notion that women could be family heads under the statutes. ${ }^{39}$

By the middle of the century, therefore, Congress had begun to protect survivors of deceased squatters. A widow could be either a claimant in her own right as head of a family or an heir. Sometimes this would lead to conflicts. ${ }^{40}$ If state statutes treated a widow as heir of less than a full fee simple in her husband's property, then it was important to know whether the federal land claim were filed by the widow in her own right as a family head or by the husband's estate for his heirs. Although Congress adopted preemption acts in part to protect family agricultural settlers, careful consideration was not given to the propriety of women, as opposed to children or other heirs, being the initial instruments for creation of such settlements. Rather, the decision was usually made by the husband or in case of his death, dictated by the timing of the family's settlement or by the terms

35. The earliest reported case construing this statute is Ely v. Ellington, 7 Mo. 302 (1842). It held that the trial court must require a plaintiff in a trespass case to prove he was a family head in order to prevail by claiming rights under the act. The problem arose because the plaintiff was only eighteen years old but had a slave with him as a cook. The language of this statute also attempted to gain some control over the quality of possession required in order to reduce fraudulent claims. This was the subject of administrative debate just before the act was passed. See 3 Op. Atty. Gen. 309 (1838). The eligibility language was continued in the 1840 extension legislation. An Act Supplemental to the Act Entitled 'An Act to Grant Pre-emption Rights to Settlers on the Public Lands,' 5 Stat. 382 (1840).

36. All of the preemption acts adopted before 1841 were retrospective in outlook; they granted rights to persons in possession during a narrowly defined time period. Many of the acts were extended, however, suggesting that permanent legislation was likely to be adopted at some point.

37. An Act to Appropriate the Proceeds of the Sales of the Public Lands and to Grant Preemption Rights, 5 Stat. 453, 455 (1841).

38. An Act to Authorize the Investigation of Alleged Frauds Under the Preemption Laws, and for Other Purposes, 5 Stat. 619 (1843). For administrative circulars on the 1841 and 1843 preemption acts see Lester, Decisions of the Interior Department, supra note 26, $\mathrm{i}$, 360-77.

39. Circular to Register and Receivers of the United States Land Office, September 15, 1841, ibid. i, 365. By 1841, it appears that the preemption acts were being liberally construed. Circulars sent to the land offices often described borderline situations and suggested that the land entries be permitted. See, e.g., a communication entitled 'Supplemental Instructions Under the Pre-emption Law of 19th June, 1834. By Order of the Secretary of the Treasury,' Treasury Report of 1837, supra note 33, 39-4l.

40. See Grant v. Cromwell, 15 Ind. 315 (1860); Cady v. Eighmey, 54 lowa 615, 7 N.W. 102 (Sup. Ct. 1880). 
of state intestate succession statutes. Since widows were gaining more protection under state intestate succession statutes as the nineteenth century developed, ${ }^{41}$ the de facto result was a trend toward greater protection of surviving spouses.

None of this federal legislation intimated that married women were entitled to buy land or that federal land was to be exempt from debts. Rather, there is explicit evidence that married women were presumed to be incapable of buying land from the federal government. The Graduation Act of $1854^{42}$ reduced the purchase or preemption price of lands opened for settlement that remained unsold for long periods. In a circular dated August 4,1854 , the General Land Office instructed its bureaucrats in land offices all over the country that 'minors, married women or others ordinarily or legally incapable of contracting, cannot enter lands under the provisions of the act. ${ }^{43}$ There is no evidence that the administrative practice prior to 1854 was any different from the rule reflected in this circular. Thus the preemption acts changed over time to provide somewhat greater protection for family members of deceased claimants; but this protection did not clearly grant widows the right to prevent their husbands' heirs from taking priority in resolution of land claims of deceased men, and wives were generally excluded from making claims. ${ }^{44}$ Nor did the preemption acts display any of the debtor relief characteristics of the early married women's acts. While the 1830,1838 and 1841 preemption acts each had provisions forbidding sale of preemption rights prior to issuance of a federal land patent, ${ }^{45}$ these provisions were inserted to reduce the influence of speculators, not to insulate assets from husbands' creditors. ${ }^{46}$ Debtor protections, save for the adoption of the short lived Bankruptcy Act of 1841 , were left primarily to the states.

41. See Chused, 'Married Women's Property Law,' supra note 1, 1404-5.

42. At Act to Graduate and Reduce the Price of the Public Lands to Actual Settlers and Cultivators, 10 Stat. 574 (1854).

43. Circular Instructions Under the Graduation Act of August 4, 1854 (October 30, 1854) in Lester, Decisions of the Interior Department, supra note 26, i, 466.

44. Total exclusion is almost surely the result of the 1854 circular language, since states and territories did not begin to give married women general rights to contract until after 1854. See Chused, 'Married Women's Property Laws,' supra note 1, 1409-10, n.263. And certainly before the married women's acts of the 1840 s, wives would be excluded under this rule. As a sidelight it is interesting to note that single women eventually won the clear right to claim under the 184 ! preemption act as 'single men.' The gender language was construed to mean 'persons.' 1867 Annual Report of the Commissioner of the General Land Office in Lester, Decisions of the Interior Department, supra note $26, \mathrm{ii}, 277$. It may well be that this result reflected practice well before 1867.

45. An Act to Grant Preemption Rights to Settlers on the Public Lands 4 Stat. 420, 421 (1830); An Act to Grant Preemption Rights to Settlers on Public Lands, 5 Stat. 251 (1838); An Act to Appropriate the Proceeds of the Sales of the Public Lands, and to Grant Pre-emption Rights, 5 Stat. 453, 456 (1841).

46. See Gates, Public Land Law Development, supra note 5, 235. Despite the provisions, the preemption laws were seriously abused. Ibid. 245-47, 395-96. 
Like the preemption acts, the early acts granting free lands to settlers displayed little interest in the role of women, except to guarantee the distribution of lands claimed by men or to attract men to distant territories. Debates on free land grants went on for many years before the Homestead Act was adopted. A stream of petitions were filed with Congress requesting free lands. ${ }^{47}$ Prior to 1862 , Congress approved a number of donation acts providing for distribution of free land to settlers in distant or dangerous territories. ${ }^{48}$ The early donation acts and the preemption acts eased some of the pressure for distribution of free land. But the preemption acts left intact the requirement that preemptors pay $\$ 1.25$ an acre for land ${ }^{49}$ and prohibited preemption in unsurveyed areas. ${ }^{50}$ By the time land prices were reduced under the Graduation Act of 1854, the homestead movement had developed into a strong political force. The Graduation Act itself was enacted as a Senate substitute for a homestead measure adopted by the House. Several senators expressed strong doubt about the power of Congress to control the disposition of privately held property. Echoing what happened four years earlier in the Oregon Donation Act debates, the Senate deleted the debt exemption provision from the homestead legislation before approving the substitution of the graduation bill. ${ }^{51}$ Congress finally passed a Homestead bill in 1860 , only to have President Buchanan veto the measure on

47. Petitions began arriving in Washington late in the eighteenth century with a plea from Ohio. Further requests came from Mississippi in 1804 and Indiana in 1806. A fairly concerted drive arose in the western territories between 1812 and 1814. Benjamin Hibbard, A History of the Public Land Policies (Madison, 1924) 349-350. Senator Thomas Hart Benton's arrival from Missouri led to reintroduction of the matter to Congress in 1825. Various free land proposals were before Congress on numerous occasions after 1825 .

48. An Act to Provide for the Armed Occupation and Settlement of the Unsettled Part of the Peninsula of East Florida, 5 Stat. 502 (1842); An Act to Create the Office of Surveyor General of the Public Lands in Oregon and to Provide for the Survey, and to Make Donations to Settlers of Said Public Lands, 9 Stat. 496 (1850); An Act to Establish the Territorial Government of Washington, 10 Stat. 172 (1853); An Act to Establish the Offices of the Surveyor-General of New Mexico, Kansas and Nebraska, to Grant Donations to Actual Settlers Therein, and for Other Purposes, 10 Stat. 308 (1854).

49. This was ameliorated somewhat by the Graduation Act of 1854,10 Stat. 574. The act reduced the price of land which had been on the market for a long time.

50. Unsurveyed lands in all areas were not preemptible until 1862. An Act to Establish a Land Office in Colorado Territory, and For Other Purposes, 12 Stat. 413 (1862). Earlier acts opened unsurveyed lands in California, Oregon, Washington, Kansas, Nebraska and Minnesota. See Gates, Public Land Law Development, supra note 5, 244.

51. House Bill No. 37 was passed 107-72 by the House of Representatives on March 6 , 1854. Congressional Globe, 33d Cong., Ist Sess. (1854) 549. Section 4 of the bill provided:

That all land acquired under the provisions of this act, shall in no event become liable to the satisfaction of any debt or debts contracted prior to the issuing the patent therefor. 
constitutional grounds. The election of Lincoln, who promised to support a free land measure, insured the adoption of a Homestead Act. One was finally approved on May 20, 1862.52

The preemption acts and the later donation statutes were parts of the same basic movement to create a landowning agricultural class in the western territories. It is therefore not surprising that the early donation acts, like the preemption acts, displayed little evidence of the contemporaneous adoption of married women's property acts at the state level. For example, the Florida Donation Act clearly was designed to attract a militia force to the southern territory. Donations were to be given to any person, being the head of a family, or single man over eighteen years of age, able to bear arms' who settled in Florida within a year after the act's adoption, and remained there for five years. If a claimant died within the five-year term, the widow and heirs took the patent in accordance with Florida intestacy law. ${ }^{53}$ This statute was very close to the Preemption Act of 1841 in its terms, even to the point of suggesting that heads of families could be women. 54 The Homestead Act later followed this model, providing free land to family heads, or 'any person' age twenty-one or over. In addition, the Homestead Act was explicit in designating widows as eligible claimants, in naming widows as first takers from deceased male claimants, and for the first time, exempting federal land grants from the claims of prior creditors. ${ }^{55}$

The Oregon Donation Act represents something of a turning point in these developments. Although the free land provisions were clearly related to the later homestead grants, the provision that a woman married to a settler on the public lands would get one half of the family's donation 'to be held by her in her own right' 56 seems at first glance to be unrelated to the

Ibid. 547. This provision provoked sharp Senate debate on the extent of Congressional authority to control the disposition of lands after title passed to private parties. Ibid. $540-43,1705,1811-13$. At the conclusion of the debate, the Senate voted 26-20 to delete the section from the bill. Ibid. 1813. A short time later, the Graduation Act was moved as a substitute, and approved. Ibid. 1832, 1844.

52. Congressional Globe, 37th Cong., 2d Sess. (1862); An Act to Secure Homesteads to Actual Settlers on the Public Domain, 12 Stat. 392 (1862).

53. An Act to Provide for the Armed Occupation and Settlement of the Unsettled Part of the Peninsula of East Florida, 5 Stat. 502, 503 (1842).

54. Both masculine and feminine pronouns were used in the act as substitutes for the term 'settler.'

55. An Act to Secure Homesteads to Actual Settlers on the Public Domain, 12 Stat. 392, 393 (1862).

56. An Act to Create the Office of Surveyor-General of the Public Lands in Oregon, and to Provide for the Survey, and to Make Donations of the Said Public Lands, 9 Stat. 496, 497 (1850). Section 4 of the act granted to persons settling in Oregon by December 1, 1850 and cultivating their land for four years '... the quantity of one half section, or three hundred and twenty acres of land, if a single man, and if a married man, or if he shall become married within one year from the first day of December, eighteen hundred and fifty, the quantity of one section, or six hundred and forty acres, one half to himself and the other half to his wife, to be held by her in her own right....' Section 5 granted to those settling in Oregon between 1850 and $1853^{\circ} \ldots$ the quantity of one quarter section, 
federal land grant movement in general or the homestead movement in particular. In fact, adoption of the married women's provisions was closely related to the debates in Congress over measures to protect settlers from speculators and creditors. Even though the Donation Act itself contained no debtor protection provisions, Congress excluded such language on a close vote after being informed (erroneously) that territorial law already provided for such an exemption, and Oregon's Territorial Legislature passed a debtor exemption provision for donation lands only during the session following Congress's adjournment in 1851. Although state married women's legislation and federal homestead acts certainly fulfilled somewhat different social needs, they both responded to at least one thread of nineteenth-century development - the desire to provide agricultural families with a firm economic foundation by distributing land unencumbered by debt. ${ }^{57}$

\section{IV}

The Oregon Donation Act was adopted after a short but tumultuous territorial history. ${ }^{58}$ From 1818 when the Treaty of Ghent was signed, to June 1846, when the United States and Great Britain settled on the boundary between the United States and what is now Canada, ${ }^{59}$ the territory was jointly occupied by British and American subjects. Until 1843, the area generally was run by Dr. John McLoughlin, head of the Hudson's Bay Company, the overseer of British interests in the Northwest. Americans began emigrating to the area in the mid-1830s, and the first major wagon train left Independence, Missouri, for Oregon in May 1843. Even without the wagon train, enough people had migrated to the fertile Willamette Valley by 1843 that agitation for some form of local government was beginning to have results. On May 2, 1843, about 100 men gathered at

or one hundred and sixty acres of land, if a single man; or if married, or if he shall become married within one year from the time of arriving in said Territory, or within one year after becoming twenty-one years of age as aforesaid, then the quantity of one half section, or three hundred and twenty acres, one half to the husband and the other half to the wife in her own right. ... When the Oregon Territory was split, the act was extended to the Washington Territory. An Act to Establish the Territorial Government of Washington, 10 Stat. 172 (1853).

57. Congress also adopted one other unusual donation act, An Act to Establish the Offices of Surveyor-General of New Mexico, Kansas, and Nebraska, to Grant Donations to Actual Settlers Therein and for Other Purposes, 10 Stat. 308 (1854). This act limited claimants to male citizens. Information on it is very scarce. The New Mexico act also appears to have been a fairly unimportant land statute. By 1904, less than 5,000 acres had been distributed under the act. Gates, Public Land Law Development, supra note 5 , 119. In contrast to the New Mexico legislation, the Oregon Donation Act was used extensively. By 1904, almost 3,000,000 acres had been distributed under the Oregon Donation Act and its continuation version in the Washington Territory. Ibid. 119.

58. For a history of the Oregon Territory see Malcom Clark, Eden Seekers: The. Settlement of Oregon, 1818-1862 (Boston, 1981).

59. Treaty With Great Britain in Regard to Limits Westward of the Rocky Mountains, 9 Stat. 869 (1846). 
Champoeg to talk over political affairs. After a close vote a crude provisional government was formed. ${ }^{60}$

As one of its first acts, the provisional government adopted a Law of Land Claims permitting individuals to record a claim for possession of up to 640 acres of land, provided that they lived upon and improved their claims. ${ }^{61}$ While the 640 -acre size was significantly larger than other American land laws, it ended up appearing in all the provisional and territorial land claim laws adopted before the Oregon Donation Act, as well as in the Donation Act itself. The 1843 land law was replaced the following year by an act permitting married males, single males over the age of eighteen, and widows to file 640 -acre claims. ${ }^{62}$ In the Organic Law of Oregon, the provisional government's constitution, which was approved by popular vote in 1845, free males were given the right to vote, but the land law returned to gender-neutral language like 'individual.' ${ }^{63}$ When, however, the Organic Law was technically amended in 1847 , both male and female language was used, suggesting that widows were still eligible to file claims. ${ }^{64}$ Shortly after the Organic Law was approved, the new legislature adopted the Code of the lowa Territory as its first set laws, ${ }^{65}$ probably because the code was known both to the residents of Oregon and to those in Washington urging creation of an officially sanctioned Oregon Territory. ${ }^{66}$

While the provisional government was struggling to establish itself, petitions, memorials and resolutions urging the United States to take control of the Oregon Territory were being submitted regularly to Congress. ${ }^{67}$

60. Frederick Holman, 'A Brief History of the Oregon Provisional Government And What Caused Its Formation,' Oregon Historical Quarterly 13 (1912) 89, 90-117. The men at Champoeg represented over sixty percent of the approximately 160 men then living in the territory. Ibid. 111.

61. Law of Land Claims, July 5, 1843, in Grover, Oregon Archives, Including Journals, Governor's Messages and Public Papers of Oregon From 1841-1849 (1853) 35. See Holman, 'Brief History of the Oregon Provisional Government,' supra note 60, 123-24. The claims were possessory because the Provisional Government recognized its inability to dispose of the full title of a sovereign state.

62. An Act in Relation to Land Claims, June 25,1844 , in Laws of a General \& Local Nature Passed by the Legislative Committee \& Legislative Assembly for Oregon Territory, 1838-1849, 77-78. [hereafter General \& Local Laws, 1838-1849].

63. Article III, Organic Laws of Oregon (1845) in Statutes of a General Nature Passed by Legislative Assembly of Territory of Oregon, 2d Sess., Dec. 2, 1850, at Oregon City (1851) 32.

64. An Act to Amend the Organic Law, December 23, 1847 in General \& Local Laws, 1838-1849, supra note 62,45 .

65. An Act Adopting the Statutes Laws of the Territory of Iowa and the Common Law, Aug. 12,1845, in Oregon Acts \& Laws Passed by the House of Representatives at Meeting Held in Oregon City, Aug. 1845 (1921) 16.

66. F.I. Herriott, 'Transplanting lowa's Laws to Oregon,' Oregon Historical Quarterly 5 (1904) 139.

67. For a summary of the petitions from Oregon residents see Pike, 'Petitions of Oregon Settlers,' Oregon Historical Quarterly 34 (1938) 216. Congress actively considered Oregon land bills for many years, starting in 1820. See Hubert Howe Bancroft, The History of Oregon, 2 vols. (San Francisco, 1935) i, 349-90; Charles H. Carey, A General History of Oregon (Portland, 1935) i, 255-59. 
Congress actively considered the Oregon question for many years, with bills calling for the occupation of the territory appearing as early as 1820.68 Even before Oregon's provisional government was established, some of the proposed legislation, particularly that of Senator Linn, called for donations of large amounts of land to settlers. ${ }^{69}$ And in early 1843, the Senate debated and passed ${ }^{70}$ a bill that extended lowa law over the Oregon Territory and called for grants of 640 acres to each white male inhabitant of the territory, plus another 160 acres if he was married, and 160 more for each child, in order to induce both men and women to make the difficult westward move. ${ }^{71}$ Even though the bill died without being passed by the House, it set a precedent for congressional adoption of a donation act with larger grants to married than to single persons. ${ }^{72}$ Later petitions from Oregon urging adoption of land legislation cited Linn's bill as an inducement to settlement. ${ }^{73}$

68. Bancroft, The History of Oregon, supra note 67, 349-90; Carey, $A$ General History of Oregon supra note 67, 255-59, 447-49.

69. See, e.g., Motion Submitted by Senator Linn in Relation to the Occupation and Settlement of the Oregon Territory, S. Doc. 25, 26th Cong., 1st Sess. (1839). Linn's early bills called for donations of 1,000 acres; later versions reduced this to 640 acres with 160 -acre increments if the claimant had a wife or children. See H.R. No. 271, 3Ist Cong., Ist Sess. 3 (1850).

70. Congressional Globe, 27th Cong., 3d Sess. (1843) 24.

71. See Congressional Globe, 27th Cong., 3d Sess. (1843) 222, App. 80.

72. The bill may have been a precursor to the later Donation Act provisions giving land to married women, but Linn's bill did not clearly provide for separate wifely title. The relevant provisions read as follows:

That provision hereafter shall be made by law to secure and grant six hundred and forty acres, or one section of land, to every white male inhabitant of the Territory of Oregon, of the age of eighteen years and upward, who shall cultivate and use the same for five consecutive years; or to his heir or heirs at law, if such there be, in case of his decease. And to every such inhabitant or cultivator (being a married man) there shall be granted, in addition, one hundred and sixty acres to the wife of said husband, and the like quantity of one hundred and sixty acres to the father for each child under the age of eighteen years he may have, or which may be born within the five years aforesaid.

Congressional Globe, 27th Cong., 3d Sess. (1843) 112. Proposals to donate land to Oregon settlers continued to appear in Congress after 1843, but none reached full floor debate until 1850 .

73. Memorial of the Legislative Committee of Oregon for the Establishment of a Territorial Government Under the Protection of the United States, S. Doc. No. 8, 29th Cong., 1st Sess., 3 (Dec. 8, 1845); Memorial of the Legislative Assembly of Oregon Praying Congress to Establish a District Territorial Government Embracing the Coast of Oregon and to Protect the Citizens in Their New Habitations, Etc., H.R. Doc. No. 42, 29th Cong., 1st Sess., 3 (Dec. 19, 1845); Memorial of the Legislature of the Territory of Oregon Praying the Confirmation of the Land Titles to the Settlers in That Territory, Etc., S. Misc. Doc. No. 3, 30th Cong., 1st Sess., 2 (Dec. 8, 1847); Memorial of the Legislative Assembly of Oregon Territory Relative to Their Present Situation and Wants, H.R. Misc. Doc. No. 98, 30th Cong., Ist Sess., 2-3 (Aug. 10, 1848); Memorial of J. Quinn Thorton Praying the Establishment of a Territorial Government in Oregon, Etc., S. Misc. Doc. No. 143, 30th Cong., Ist Sess. 2, 11 (May 25, 1848). 
Once the boundary issue was settled with Great Britain, Congress again began to consider resolution of the Oregon question. After lengthy debates, Congress established a government for the Oregon Territory, covering what is now Oregon, Washington, Idaho, and parts of Montana and Wyoming. This act provided for white male suffrage, and continued in force all the laws for the provisional government except 'all laws heretofore passed in said Territory making grants of land, or otherwise affecting or incumbering the title to lands, shall be, and are hereby declared to be, null and void. ${ }^{74}$ Since Congress did not simultaneously enact a land bill, a significant vacuum was created.

When word of Congress's failure to adopt land legislation reached Oregon, controversy emerged over how to protect claims to land under the laws of the provisional government. An Association for the Protection of Land Claims was formed, as was a group opposing self help. ${ }^{75}$ The territorial legislature took up the dispute the following year, noting, 'Doubts have arisen whether, or not, the land law of the late provisional government is in force.' The old provisional government land law was 'revived,' except that claims under it were expressly limited to white male citizens over age eighteen. ${ }^{76}$ Widows therefore were left in a worse situation than under the Land Law of 1844. This action followed the approval of legislation by the last session of the Provisional Legislature which provided that widows could reside on their deceased husbands' claims only until death or remarriage and that the land claims descended as personal property to husbands' heirs. ${ }^{77}$ These actions make it difficult to imagine that a strong women's property reform movement existed in Oregon just before the Donation Act was passed.

The disarray in the land situation required resolution. In 1849 , the new Oregon Territory sent its first delegate, Samuel R. Thurston, off to Congress. Although it is not known who actually drafted the Oregon Donation Act, there is little doubt that Thurston worked hard on the measure. ${ }^{78}$ Thurston and his colleagues had a number of models from which

74. An Act to Establish the Territorial Government of Oregon, 9 Stat. 323, 325, 329 (1848).

75. Oregon Spectator, July 27, 1848. Formed on July 15, 1848, the Association resolved, among other things, to adopt methods to protect claims 'which shall not only be cheap, but speedy.' Ibid. A later resolution called for the establishment of arbitration panels and enforcement teams. Oregon Spectator, August 10, 1848. Editorializing against the potentially lawless association also appeared. Oregon Spectator, August 24, 1848.

76. The language in the text was in the preamble to An Act to Prevent Injuries to the Possession of Settlers of Public Lands (Sept. 12, 1849) in Statutes of a General Nature Passed by Legislative Assembly of Territory of Oregon, 2d Sess., Dec. 2, 1850, at Oregon City (1851). The 1843 Code of lowa was also adopted in large part at this session of the legislature. An Act to Enact and Cause to be Published a Code of Laws (Sept. 29, 1849) in General \& Local Laws, 1838-1849, supra note 62, 103.

77. An Act to Secure to the Heirs of Deceased Persons the Value of Their Land Claims (Feb. 15, 1849) in General \& Local Laws, 1838-1849, supra note 62, 61.

78. Thurston spent a significant amount of time on the question. See Diary of Samuel Royal Thurston, Oregon Historical Quarterly 15 [hereafter Thurston Diary] (1914) 153, 181, 
to draw material for the land bill. As already noted, Oregon's provisional government had dealt with land questions before the territory was organized in 1848. While the federal government slowly moved toward the creation of the Oregon Territory, the settlers established a de facto land system in which possessory interests short of absolute title were allocated. These preexisting claims made it difficult for Congress to distribute land in smaller bundles than had been distributed by the provisional government, at least for settlers already in the territory. ${ }^{79}$ This territorial model, however, did not display even a glimmer of interest in married women's property reform.

Prior proposals for federal land grant legislation for the Oregon Territory probably were more significant for the development of the married women's provisions in the Donation Act. Most of the basic provisions of the act as adopted by Congress were present in previously debated bills. Virtually all the old proposals, including the bill passed by the Senate in 1843 , called for larger grants to married men than to single men. Thurston and his colleagues certainly knew of these old bills. During his initial months in Washington, Thurston noted in his diary that he read a great deal of material on Oregon in the House and Senate Journals, reviewed prior legislation and looked over other items. ${ }^{80} \mathrm{He}$ also discussed the Oregon land bill with Senators Douglas and Benton. ${ }^{81}$ Even though the old legislative proposals for larger grants to married couples were framed to attract women to the territory rather than to embody state-level women's property reforms, they may have spurred Thurston or others to consider adapting the state married women's property reform movement to the needs of present and future Oregon inhabitants.

Those in Congress must also have known about the widespread state reforms in married women's law. The first wave of married women's

186, 191-204; White, 'The Career of Samuel R. Thurston in Iowa and Oregon,' Iowa Journal of History and Politics 14 (1916) 239, 260-61; Clark, Eden Seekers, supra note $58,236-39$. In his later reelection letter to his constituents, Thurston wrote that the land issue was his top priority. Letter to the Electors and People of the Territory or Oregon 3: Thurston Papers, MSS 379, Oregon Historical Society (Nov. 15, 1850). Letters to Thurston's wife, Elizabeth, discussing the bill, were written on Jan. 2, 1850 (tells of bill he submitted extinguishing Indian title as a first step towards the land law); June 9, 1850; August 11, 1850 ('got my land bill through the House'); Sept, 16, 1850 (delays of 'my land bill' in Senate); Sept. 22, 1850 (passed Senate); Sept. 29, 1850 (passed). All of Thurston's letters to his wife are in the Thurston Papers at the Oregon Historical Society. Thurston also discussed the bill with Governor Fitch of the Committee on Territories and with Land Office personnel. Thurston Diary, 191-95.

79. This was recognized by the Land Office. In the Annual Report of the Commissioner of the General Land Office, House Ex. Doc. 5, 3 lst Cong., Ist Sess., 17 (1849) a call was made for "further legislation ... to recognize all old bona fide settlement claims, to secure the owners in their improvements, to give them a fee title in their lands, and to invite emigration by liberal donations to those who will make that country their home.'

80. He got the House journals from 1837 on and extracted relevant material. Thurston Diary, supra note $78,162,166-68$. He noted his intention to do the same for the Senate. Ibid. 166. He also hunted up old House bills and Senate documents on Oregon; ibid. $167,168,169$, and reviewed old laws on Oregon; ibid. 161, 165, 166.

81. Douglas: ibid. $175,181,183,184$. Benton: ibid. 163, 173, 175, 176, 185. 
property acts had been adopted in most states by 1849 , the year Thurston went to Washington, D.C. Thurston, for example, was exposed very directly to such legislation. The year before he left his home state of Maine, the legislature adopted a married women's act. ${ }^{82}$ The lowa territorial legislature followed suit while Thurston was editing the Burlington [lowa] Gazette. ${ }^{83}$ While there is no evidence that Thurston was associated with the drafting of either statute, he almost certainly knew about them, and, as the possessor of a practicing lawyer's library ${ }^{84}$ probably carried one or both of the acts with him to Oregon. The Oregon provisional government's use of the Iowa code (not including the married women's act) also suggests that Thurston was knowledgeable about Iowa law.

The background preparatory work done by Thurston during his first months in Washington first bore fruit on February 25, 1850, when he introduced and obtained passage of a resolution in the House of Representatives calling on the Committee on Territories to investigate the need for an Oregon land bill. ${ }^{85}$ The resolution mentioned land donations and the inducements held out by prior congressional action, but was silent on the married women's issue. Almost two months later Representative Fitch of the Committee on Territories reported out House Bill No. 250. The bill was read twice and referred to the Committee on Public Lands, from which it emerged only two days later. ${ }^{86}$ Such timing suggests that the major drafting work was done on the bill while the Committee on Territories had Thurston's resolution under consideration. ${ }^{87}$ As the bill emerged from the Territories Committee, it contained the language giving land grants to married women in their own right. ${ }^{88}$

82. An Act of March 22, 1844, to Secure to Married Women their Rights in Property, ch. $117,1844 \mathrm{Me}$. Acts 104. Section 1 of the act provided that married women 'may become seized or possessed of any property ... in her own name, and as of her own property.'

83. An Act Concerning the Rights of Married Women, Jan. 2, 1846, ch. 5, 1845 lowa Terr. Acts 4 (1846). Section 2 of the act provided that married women shall possess ... [property] in her own right, and the same shall in no case be liable to the debts of her husband.' Like the Maine act, this language tracks that of the Oregon Donation Act very closely. Thurston edited the Burlington Gazette from 1845 to 1847 before he went to Oregon. Harvey W. Scott, History of the Oregon Country, 2 vols. (Cambridge, Mass., 1924) ii, 242. This was confirmed by my perusal of newspapers at the Library of Congress.

84. Elizabeth Odell, Biography of Samuel R. Thurston, 1-2 (Unpublished paper, MSS 379, Oregon Historical Society, 1879) 3.

85. Congressional Globe, 31 st Cong., Ist Sess. (1850) 413.

86. Congressioal Globe, 31st Cong., 1st Sess. (April 22 and 24, 1850) 791, 814.

87. In a letter to Thurston on the section of the Donation Act denying Dr. McLoughlin his land claim, a matter of great controversy in Oregon, Fitch acknowledges that 'the Committee on Territories . . . instructed me to draft it [the Donation Act].' Letter from Graham N. Fitch to Samuel R. Thurston, dated December 9, 1850, as published in the Oregon Spectator, February 6, 1851.

88. Just before the House Public Lands Committee reported out its bill, the Senate was also visited with a donation bill, S. 202, which was referred to the Senate Committee on Public Lands. Congressional Globe, 3 lst Cong., Ist Sess. (April 16, 1850) 743. S. 202 was identical with H.R. 250. 
Very little is known about the bill's drafting while in the Committee on Territories. Thurston spoke with Representative Fitch, who sat on Territories, and the land commissioner ${ }^{89}$ during the drafting stage, and, during the period just before the bill was introduced in both the Senate and the House, he visited at least twice with the chief clerk of the Survey Department of the Land Office who was 'drawing' the bill. ${ }^{90}$ Five days after his last visit at the Land Office, Thurston reported that the bill had been introduced in the Senate and that the House Committee on Territories had reported out the bill with a unanimous vote of approval. ${ }^{91}$ The list of amendments made to the bill by the Committee on Public Lands made no reference to the donation sections of the bill, further confirming that the Territories Committee was the place where the primary drafting of the bill occurred. ${ }^{92}$

The marked-up bill in the Archives contains surprising marginal notes suggesting that the Committee on Territories deliberated the donation provisions. The crucial operative language donating land to a married

89. On March 16 Thurston visited with Fitch to urge a favorable report on the land bill. Thurston Diary, supra note 78, 191. Two days later, Thurston wrote that he planned to meet Fitch 'to draw up the land bill for Oregon.' Ibid. 192. He then reported on an evening visit to Representative Fitch on Sunday, March 17, 1850. 'Not very right 1 admit, wrote Thurston, referring to the time and day of the business call. Thurston also visited with Fitch on the land bill on March 19. Ibid. 192. The Land Commissioner visit was on March 18. Ibid.

90. Thurston called on the Chief Clerk on April 9, 1850 and returned on April 13 'to see that our land bill was ready by Monday.' Ibid. 194-95. Clearly the bill was handled by a number of people, including Fitch, see supra note 88, Land Office personnel, and Thurston. Pinpointing the principal draftsman is impossible.

91. Thurston Diary, supra note 78,195 . This diary entry was on April 18, 1850, the same day the bill was introduced in the Senate and four days before the Territories Committee reported the bill to the floor. See ibid. 196, for the April 22 entry on the bill's reporting and referral to Public Lands. National Archives material confirms Thurston's diary entry. While the Archives cupboard was bare on Thurston's dealings with the Chief Clerk at the Survey Division of the Land Office, luck was better with legislative records. I looked through items from Record Group 233 at the Archives, including the files of the U.S. House of Representatives, 31st Cong., on H.R. 250, the Territorial Committee Docket books and the volume of engrossed bills containing the Donation Act. An entry for February 25, 1850, in the Docket Book, Committee on Territories, 31 st Cong., 1st \& $2 \mathrm{~d}$ Sess., confirms that Thurston presented a resolution which was referred to the committee, where it was laid on the table. This entry is followed by a note which reads as follows:

Having been referred to Mr. Fitch, he now, April 17th, 1850, reports Bill accompanied with Report-adopted by Committee and Mr. Fitch instructed to Report the same to the House, to be referred to Committee on Public Lands-Bill \& Report to be printed.

The jacket of the original bill on file in the National Archives also contains notations reflecting the bill's movement from the Committee on Territories to the Committee on Public Lands.

92. The National Archives file on H.R. 250 contains a document entitled 'Amendments to House Bill 250 Made by the Committee on Public Lands.' It is this document which lacked any references to the married women's provisions of sections 4 and 5 . 
woman 'in her own right' was inserted in both section 4, which donated land to existing settlers or those who arrived before the end of 1850 , and section 5 , which donated land to future emigrants, in a handwriting clearly different from that of the basic text of the bill. In addition, detailed provisions that would have permitted married women to use and transfer their donation claims without interference from their husbands or their husbands' creditors were contained in the original handwritten version of section 5 . These lines were, however, crossed out. ${ }^{93}$

The consequences of these markings are not altogether clear. It is possible that the changes were simply designed to make sections 4 and 5 consistent in their terminology. There was nothing in the bill that clearly demanded different treatment of existing and future settlers. It is possible that section 5 was drafted differently from section 4 because enticements were necessary only to attract future female settlers west. If that is the explanation for the original version, the committee must have concluded that equal rewards were required for both past and present fortitude in besting the frontier.

It is also possible that the differences between the content of the original section 5 and the version emerging from the committee were quite significant, that the final version was decided upon not just to make the sections consistent but to reach a compromise. The crossed-out segment of section 5 contained language that could have been read to move significantly beyond the content of almost all the state married women's acts adopted before 1850 . Most of these acts were very short. They generally contained nothing more than statements exempting married women's property from the debts of husbands. Some of them also contained general language permitting married women to hold separate estates in property, presumably without the use of a trustee as was often required by the rules governing the equitable separate estate of a married woman. By and large these statutes contained no specific language giving married women the right to contract about their property, write wills or manage their assets. The common-law rights of a husband to manage his wife's real property and to gain title to her personal property were not specifically abrogated until later in the century. The crossed-out provisions in section 5 would have permitted married female owners of donation lands to sell, devise and use the land 'at their own pleasure' without the control of their husbands, and without liability for

93. The basic text of the handwritten versions of H.R. 250 was not in Thurston's writing. After the language in the adopted version of section 5 reading '. . . in her own right to be designated by the Surveyor General as aforesaid,' the version deliberated upon by the Committee on Territories had this crossed-out language:

and all lands herein provided for to be donated to females shall forever be the property of such females in their own right; to be by them held, used, aliened, and devised at their own will and pleasure, and not subject to the control of their husbands or be liable for their debts without the consent of such females first had in writing in such manner as may be provided for hereafter by the Legislative Assembly of Oregon Territory.

This language was never discussed on the floor of the House. 
husbands's debts. Not even the famous New York married women's act adopted in 1848 contained such language. ${ }^{94}$

It is therefore reasonable to assume that objections were raised to the draft bill in committee, and that the more ambiguous language eventually adopted by Congress was substituted. Such substitutions had occurred at the state level when controversy arose over the content of proposed married women's acts, and there is no reason to rule out the possibility here. This explanation would suggest that the committee, like many in modern Congresses, agreed to tone down the bill and leave it to the courts to work out the meaning of the language. Those of Machiavellian bent might even suggest that this was done knowing that many state courts were narrowly construing married women's acts to insure that they did not interfere with the basic rights of husbands to control their wives' property during marriage. ${ }^{95}$

Other congressional materials available on the Donation Act do not completely resolve the ambiguities in the committee deliberations. H.R. 250 was accompanied by a report from $\mathrm{Mr}$. Fitch of the Committee on Territories, which answered the inquiries in Thurston's original House resolution of February 25 . The report noted that a liberal donation of land to persons risking the long trip west 'was the public sentiment' of the 1840s, and that such donations would have been made before 1848 but for the treaty complications with Great Britain. The report summarized congressional actions from 1840 to 1850 and acknowledged that inducements to emigation were created by all the consideration given to land donations. Congress's failure to act, the report argued, caused substantial reductions in the numbers of persons going to Oregon. ${ }^{96}$ But despite the marking up of the married women's provisions in the bill, the report was silent on this aspect of the legislation. On May 22, 1850, H.R. 250 emerged from the Committee on Public Lands, unaccompanied by a further report. ${ }^{97}$

The only other extant congressional document of note on the bill is an undated 'Letter of the Delegate From Oregon to the Members of the House of Representatives, in Behalf of his Constituents, Touching the Oregon Land Bill.'98 It is not known when the letter was delivered to the House

94. See Chused, 'Married Women's Property Law,' supra note 1, 1410-11.

95. Ibid. 1400.

96. H.R. No. 271, 31 st Cong., 1st Sess. (1850). In 1847, the report suggested, when "people were expecting a liberal [land] policy to be adopted,' 1,000 wagons made the trip west. By 1849, the number was down to fifty. H.Rep. No. 271, 31 st Cong., 1st Sess. 4 (1850).

97. Congressional Globe, 31 st Cong., 1st Sess. (1850) 1034. The bill emerged with a few amendments not relevant to this study.

98. This undated document is in the Thurston Papers, MSS 379, Oregon Historical Society. Oregonians were apparently unaware of the letter's content until after House debates were concluded. White, 'The Career of Samuel R. Thurston,' supra note 78, 239, 262-63 notes that the letter first appeared in the Oregon Spectator on September 12, 1850. My own review of the Spectator confirms this. From comments in the Spectator, it appears that the letter was in circulation in Oregon sometime in August after being privately printed on Thurston's order. Oregon Spectator, August 29, 1850. The Oregon Donation Act, as it emerged from the House Public Lands Committee was published in the Spectator on September 5, 1850. 
membership. ${ }^{99}$ Thurston opened the lengthy letter ${ }^{100}$ by thanking the members for their 'action in the House, the other day, on the Oregon Land Bill.' This probably referred to floor consideration given the bill on May 29, 1850 , since later portions of the letter referred to amendments adopted on that day. The letter ended with a plea to take up the bill again for consideration. Thurston must have been trying to end a long hiatus in the debate which occurred after May 29. The letter, probably distributed sometime during this break in the floor debates, didn't bear fruit until August 8 , when debate resumed and the bill was approved. ${ }^{101}$

In any case, the opening segments of the letter recounted the history of Oregon and the inducements held out to emigrate by Congress's deliberations of land donations. Thurston then reviewed various pending amendments and other issues about the bill. With respect to the married women's provisions, Thurston wrote:

The feature of the bill securing one-half of the land to the wife, is deemed to be just. The law of "homestead exemption," is fast becoming the doctrine of the day. This provision is merely the same law in substance. Besides, emigrating to Oregon from the States, places the female beyond the reach of her kindred and former friends; and it is certainly no more than right to place some little means of protection in her own hands. But the object is to produce a population, and this provision is an encouragement of the women to peril the dangers and hardships of the journey.

This little paragraph is of some help in deciphering the House debates. Thurston's reference to the married women's provision as part of the homestead exemption movement is not without ambiguity. Certainly the Donation Act was a predecessor to the Homestead Act's distribution of free land. ${ }^{102}$ But by and large the language 'homestead exemption' was used in the mid-nineteenth century to refer to debtor exemption provisions, not free land. States had begun to adopt laws prohibiting attachment of houses and a small segment of land around them during the period in which married women's laws began to appear. ${ }^{103}$ Thurston's writing of homestead exemptions therefore suggests that donation lands were to be insulated from

99. Thurston noted in his diary that he worked on an address to his constituents on April 19 to 23 , the days surrounding the introduction of the Donation Bill. Thurston Diary, supra note 78,196 . This may refer to either the letter or a long address on general subjects printed serially in the Oregon Spectator on September 26, October 3, October 10 and October 17, 1850. The most logical conclusion is that it refers to the address, since the word 'address' is used in the diary. In any case, for reasons suggested in the text, the letter was probably not distributed immediately after the diary entries were written.

100. The pamphlet version of the letter is eight pages long in very small type. The newspaper version covers much of the first and second pages of the Spectator, September 12, 1850.

101. Congressional Globe, 31st Cong., 1st Sess. (1850) 1075, 1548.

102. See James M. Berquist, 'The Oregon Donation Act and the National Land Policy,' Oregon Historical Quarterly 58 (1957) 17.

103. Chused, ‘Married Women's Property Law,'supra note 1, 1402. 
creditors. This is confirmed by the May 29 debates on the Donation Act. On that day, an amendment was offered by Representative Sackett to insert in the bill the language, 'And no interest in the part so held by the wife in her own right, shall be liable for, or subject to sale upon the debts of her husband.' Sackett briefly explained that the married women's provisions of the bill could be 'practically defeated by a rule of common law which allows the property to pass from her, under certain circumstances, at death of the husband.' 104 The amendment was then agreed to without further debate. Sackett's proposal took part of the content of the original committee version of section 5 but lacked language giving married women management and transfer rights over donation lands.

Thurston's other statements in his letter to the House membership about attracting women to Oregon reflected the fact that Oregon's population was heavily male. Census data for 1850 show that there were about two to three times as many men as women age twenty to fifty. ${ }^{105}$ Although the Oregon census data for 1850 has been challenged for its accuracy on a number of issues, ${ }^{106}$ there is little doubt that men outnumbered women. The shortage of females, however, was not uniform throughout the territory. Towns had significantly fewer women than agricultural areas, and birth rates were well above the national average. There is little reason to believe that Oregon's rural areas developed in patterns different from those in other, older frontier zones. ${ }^{107}$ Nonetheless, it is easy to see how Thurston could use the shortage

104. Congressional Globe, 3 Ist Cong., 1st Sess. (1850) 1094. Sackett also strongly opposed Thurston-backed amendments to prevent Blacks and aliens from taking donation claims. Ibid. 1095-96.

105. Data from the Census of 1850 , Table LIX-Proportion of White Males to Females, $\mathbf{H}$. Misc. Doc. No. 686, 32d Cong., 2d Sess. 2 (1850), produce this table:

$\begin{array}{cc}\text { Age } & \text { \% Female } \\ 0-4 & 93 \\ 5-9 & 103 \\ 10-14 & 97 \\ 15-19 & 78 \\ 20-29 & 34 \\ 30-39 & 41 \\ 40-49 & 47 \\ 50-59 & 39 \\ 60-69 & 37 \\ 70-79 & 31 \\ 80-89 & - \\ 90-99 & 100 \\ 100+ & - \\ \text { Age NA } & 71\end{array}$

106. See Douglas, 'Origins of the Population of Oregon in 1850,' Pacific Northwest Quarterly 41 (1950) 95.

107. See William Bowen, 'The Oregon Frontiersman: A Demographic View,' in Thomas Vaughan, ed., The Western Shore (1975) 181, 185-92. A much more complete conclusions in this article may be found in William Bowen's thesis, 'Migration and Settlement on a Far Western Frontier: Oregon to $1850^{\prime}$ (Unpublished thesis, 1972). Some areas, such as California, had enormous gender population disparities during mineral 'rush' eras. Ibid. 189. 
of women as a justification for the donation bill. Even though other frontier areas had similar population problems, this fact probably was not known to Thurston's colleagues. In addition, supporters of the prior proposals to donate land in Oregon had urged that more land be given to married men to attract women west. Certainly the argument sounded plausible, given the distant locale at stake. ${ }^{108}$ Thus the House defeated attempts to remove the married women's provisions from the bill. Although Representative Potter probably had his facts right when he argued that men were taking their families to Oregon and that incentives were not needed to entice women to the territory, his efforts to delete the married women's provisions failed. ${ }^{109}$

For the most part the rest of the House debate dealt with issues other than married women. The bill was caught up not only in the politics of the Northwest but also in the controversy over slavery then raging in Congress. Lengthy debate occurred over the wisdom of permitting non-whites to take donation claims. The House also discussed exclusion of Hudson's Bay Company employees as eligible claimants, grants to aliens desiring to become citizens of the right to claim a donation, and salary and expense levels for an Oregon land office. 110

On August 9, 1850, the day after House passage, H.R. 250 was read twice in the Senate and referred to the Public Lands Committee where companion bill S. 202 had been pending since April. The bill was reported out of committee with amendments the following week. ${ }^{111}$ Debate began on September 3, and continued sporadically until the 19 th. ${ }^{12}$ The first matter

108. Thurston certainly believed it. He wrote to Mr. Philip Foster in Oregon on June 30, 1850 , about the pending land bill, saying: 'I shall get the land bill passed, and if so, you may recon, that fifty thousand persons will emigrate to Oregon from the states in the next three years. I know there are extensive preparations for this purpose now being made, and I can say to you with all confidence that you may rely on a prompt market at home for all the people in Oregon can produce hereafter.' Philip Foster Papers, MSS 996, Oregon Historical Society.

109. Congressional Globe, 31 st Cong., 1st Sess., (1850) 1080. He was trying to amend the bill when another amendment was pending before the House. He later tried and failed to delete the entire donation section. Ibid. 1095, 1547. Neither Thurston's diary nor his letters to his wife refer to Potter. I don't know if Thurston talked to him about his amendments. Mr. Potter was reasonably accurate in his portrayal of reality, at least as to agricultural lands. See supra notes $105-7$ and accompanying text. An attempt to reduce the size of the donation grants also failed. Ibid. 1094.

110. Congressional Globe, 3 Ist Cong., Ist Sess., (1850) 1075-80, 1090-93.

111. Ibid. 1554, 1588.

112. During this period, Thurston despaired of gaining passage of the Donation Act. On September 3, 1850, after the Senate declined to move forward on the bill, Thurston wrote to William Meek complaining in somewhat irrational fashion of interference from the War Department. The letter was printed in the Oregon Spectator of October 31,1850 , followed by an editorial note:

The above was handed to us by $\mathrm{Mr}$. Wm. Meek, with a request that we publish it in our first issue. We do not wish to create any unnecessary alarm by so doing. The gentleman himself is undoubtedly excited.

There is much secondary commentary suggesting that Thurston was suspicious and duplicitous. See e.g., Clark, Eden Seekers, supra note 58, 237-38; White, 'The Career 
taken up was a Senate Public Lands Committee amendment to delete the House-inserted provision protecting wives' donation lands from husbands' creditors. ${ }^{113}$ Those supporting the amendment argued that the debtor exemption provision was unconstitutional, that it was inappropriate for Congress, rather than the states, to annex such a condition to private land ownership, and that Oregon statutes already contained such a provision. ${ }^{114}$ The Senate agreed to delete the exemption. ${ }^{115}$ A later attempt to insert a much broader provision insulating all donation lands from all creditors failed badly. ${ }^{116}$ The Senate was not yet ready to adopt a Homestead Act. ${ }^{117}$ On September 24, when the bill returned to the House after Senate adoption, the House concurred in the Senate amendments, and the bill was passed. 118 Thus, the Donation Act as it emerged from Congress provided that married women could take title to land, but without express language establishing the debtor exemption protection commonly afforded by state married women's acts. Congress was still reluctant to enact a 'local' debtor protection measure.

of Samuel R. Thurston,' supra note 78, 239, 261-64; Bancroft, History of Oregon, supra note 68 , ii, 114-38. While some of the more unrestrained criticism may be overdone, there is little doubt that Thurston was very controversial by 1851 and that he would have had opposition during his reelection campaign had he survived.

113. Congressional Globe, 31 st Cong., 1st Sess. (1850) 1739.

114. This was erroneous. Oregon did not adopt such a provision until 1852. See infra, note $150-57$ and accompanying text.

115. The Congressional Globe reported that the amendment to delete the provision failed by 17-24 vote. Congressional Globe, 31st Cong., 1st Sess. (1850) 1739. For reasons which are completely unexplained in the Globe, the amendment proposed and supposedly defeated in the Senate was reported as having been adopted by the Senate when the bill was sent back to the House for its concurrence with the Senate amendments. Since the engrossed version of the bill in the National Archives shows that the amendment was adopted by the Senate it is likely that the Congressional Globe was in error when it reported the failure of the Senate amendment to delete the husbandly debt provision.

116. Ibid. 1843-44. The vote was 44-3. The dismal fate of the proposal must have been due in part to a desire by many not to clutter the bill with so many amendments that the House would lack time to pass the bill before the session ended. Sentiments against the amendment on its merits, of course, also played a role.

117. Section 5 of the bill, which donated lands to future settlers, created much more controversy in the Senate than Section 4. Section 5 was seen by some as a giveaway, a homestead. Florida Senator Yulee's motion to delete Section 5 was withdrawn, but only after the time for making a future claim was reduced from five to three years. Ibid. 1841-1845. Other than the debt provision, the debates did not focus specifically on the married women's issue, though family migration was much discussed. A variety of other amendments were debated, ibid. 1840-1848, 1869, before the bill was passed by the Senate. Among them was a proposal to attach a homestead act applicable to all territories. It got only three votes, though sentiment for a homestead act unattached to other legislation probably ran significantly higher.

118. Ibid. 1953. 
The multitude of forces pushing Congress to adopt a land bill for Oregon probably gave the territory's representative more political power than is normally the case with non-voting delegates. It is generally recognized that Thurston obtained the passage of a great deal of territorial legislation in addition to the Donation Act.119 The Donation Act also contained provisions, other than the grants to married women, for which only Thurston could have been responsible. ${ }^{120}$ It is therefore highly unlikely that the House version of the Donation Act contained any provisions strongly opposed by Thurston. The scope of his influence provides additional evidence that Thurston was responsible for altering the language in the old Linn bills so that married women could obtain donation lands in their own right. Further support for this theory is provided by Thurston manuscripts. Political statements, essays and personal letters provide enough information to suggest that Thurston was sympathetic to efforts to reform married women's property law. These manuscripts are particularly interesting for the light they shed on the attitudes of nineteenth-century men. To the extent that Thurston's views mirrored those of his peers, it is easy to see why the early married women's property acts were so narrow in scope.

Some time before Samuel Thurston graduated with the Bowdoin class of 1843 and moved to Iowa two years later, probably while he was a student in the Maine Wesleyan Seminary in Readfield, he wrote an essay on female virtue. ${ }^{121}$ 'As strong as may be the giant man,' Thurston wrote, 'yet he is so happily weak that he is easily guided and directed by one more virtuous than he. On this one rests the vital consequence of much, and the reward of her virtue cannot be estimated by moral skill, till the last sand grains shall fall from the glass of time.' Thurston, like many others of his time, felt that women were society's conscience, they guarded 'the Thermopylàe of Religious virtue.' But Thurston went one step further, writing that women were in need of weapons to protect the better virtues of society. 'Let no one say longer,' Thurston concluded, 'that preparation and preparatory skill are

119. Clark, Eden Seekers, supra note 58, 237; White, 'The Career of Samuel R. Thurston,' supra note $78,239,257-61$.

120. The major provision dealt with the land claims of William McLoughlin, the head of the Hudson's Bay Company. Thurston saw to it that Section 11 of the bill contained language depriving McLoughlin of his land in Oregon City. This episode created-a great deal of controversy. McLoughlin, though head of the Hudson Bay Company, was highly respected by many in Oregon. See, e.g., Bancroft, The History of Oregon, supra note 67, ii, 117-28; Clark, Eden Seekers supra note 58, 237-39.

121. Scott, History of the Oregon Country, supra note 83, 242. Odell, 'Biography of Thurston,' supra note $84,1-2$. Thurston was born in 1816 and died at age thirty five in 1851. Odell was Thurston's wife. She remarried many years after Thurston died at sea in 1851 on his return voyage from the 31 st Congress. The essay on virtue, found in the Thurston Papers, MSS 379, Oregon Historical Society, is signed, but untitled and undated. The essay's first line reads: 'Seminary. Classical Department. No. 5.' The presence of the 'semimary' language suggests it was written at Readfield. 
not due and just to such distinguished heroins [sic]: But instead of suppressing the sciences and literary acquirements from the refining souls of the female sex, let them be favoured with the means to obtain them.' Such sentiments about educating women reflected a growing acceptance of female schooling in the early nineteenth century. Women's education grew dramatically after the Revolutionary War, and women entered universities for the first time during the era in which Thurston wrote. ${ }^{122}$ Though his style is flowery, there in no doubt that Thurston's little essay spoke to the more liberal sentiments of his day, especially in his advocacy of female education in science and literary acquirements. ${ }^{123}$

Similar ideas were expressed in a number of ways in the extant letters Thurston wrote to his wife Elizabeth between August 16,1849, while he was waiting for passage to San Francisco at Astoria, Oregon, and July 9, 1851, shortly before he began his fatal return trip from Washington, D.C. His letters contained much that was traditional for men to tell their distant spouses in Thurston's time-numerous requests to educate his son carefully in preparation for a legal career, solicitous warnings to be careful, detailed instructions on whom to stay with and how to manage the farm, constant ruminations on death. Though much of this probably was a necessary consequence of Thurston's being away from home, there were also significant amounts of material suggesting that he was somewhat more concerned with the education and public role of his wife and baby daughter than many men of his time.

The tone of the correspondence was set very early. On September 30, 1849, while waiting in San Francisco for passage to Panama, Thurston wrote of detailed money matters, directing his wife on how to invest their funds, laying out their investment strategy, and instructing his wife to keep her monetary matters secret. ${ }^{124}$ The letter's paternalism was balanced somewhat by his willingness to entrust his wife with much of their financial dealings during his absence, by his description of political and social ideas to his spouse, and by his concern over the education of his daughter. After

122. See Chused, 'Married Women's Property Law' supra note 1, 1416, 1421.

123. There is also evidence that Thurston's wife took her husband's ideas seriously. She participated in a number of public charitable activities outside the home. During Indian conflicts in 1848, Mrs. Thurston was appointed secretary at a meeting called 'to consult upon the best means to aid in relieving the necessities of the soldiers.' The women gathered clothes for the soldiers and sent them off accompanied by a note of thanks. W.H. Gray, A History of Oregon, 1792-1849 (Portland, 1870) 570-72. During the Civil War years, Mrs. Thurston was active in the Oregon Sanitary Aid Society. Julie Roy Jeffery, Frontier Women: The Trans-Mississippi West, 1840-1880 (New York, 1979) 181-82. In 1863, speaking before a gender-mixed audience at an evening 'entertainment, 'she urged her colleagues to participate in aiding the Union case without fear of overstepping 'the bounds of propriety.' Speech of Elizabeth Thurston, Thurston Papers, MSS 379, Oregon Historical Society.

124. A large number of letters talk about financial matters. Sept. 30, 1849; Jan. 7, 1850; Apr. 15, 1850; Aug. 4, 1850; Sept. 22, 1850; Dec. 15, 1850; Feb. 9, 1851; Feb. 28, 1851; Mar. 8, 1851; Mar. 11, 1851. The last spate of money letters were laced with talk of death, as if Thurston were getting his affairs in final order. 
finishing his investment instructions Thurston wrote, 'So you see my dear, I am expiating on things of this world, as tho life was certain. I do not think it wrong for me to converse thus with you, for it is hightly proper that ones wife should be fully acquainted with his business affairs.' Before closing, Thurston admonished, 'I want you to spare no pains, in educating and properly training the children.'

Thurston discussed political and social ideas in a number of letters. For example, on December 15, 1849, while the thirty-first Congress was struggling to organize in the face of strident sectional and party rivalries, Thurston wrote a long letter describing the Wilmot Proviso and the nullification doctrine, and bemoaning his inability to get paid until Congress selected its leadership. In the mixture of paternalistic and liberal impulses so typical of Thurston, he instructed his wife, 'You must, now, remember this explanation [of the Wilmot Proviso], so that if the subject should come up in conversation you will understand it, and know how to speak of it.' Other letters provided information on congressional dealings, ${ }^{125}$ and the bill to terminate Indian title in portions of the Oregon Territory, ${ }^{126}$ the land bill, ${ }^{127}$ slavery, ${ }^{128}$ Oregon politics, ${ }^{129}$ and other matters. ${ }^{130}$

Among the most interesting letters are those that discussed the education of Thurston's children and the role of his wife Elizabeth in that task. A number of letters briefly mentioned the need to educate the children, especially George Henry. ${ }^{131}$ In others, Thurston spent a great deal of time on the subject, providing a detailed view of the future roles he wished his family to play. There is no doubt that Henry Boy and Lissy ${ }^{132}$ were to fill different roles. George Henry was to be a public figure, a 'great,' 'distinguished'

125. Jan. 2, 1850.

126. Jan. 2, 1850; June 9, 1850.

127. Aug. 11, 1850; Sept. 16, 1850; Sept. 22, 1850; Sept. 29, 1850.

128. Sept. 16, 1850. Thurston was strongly anti-slavery, though opposed to allowing freed Blacks to move to Oregon. On September 16, 1850, Thurston wrote to his wife:

By the way, Wesley Shannon writes me that amids the utmost universal approbation of my speech [on California], old Col. Ford is opposed to it, because it does not favor slavery. Poor old sot! I am ashamed that there is one man in Oregon who would if he could curse Oregon by the introduction of a servile race whose presence would at once black the very heart of our prosperity-free white labor. But, dear wife, I have no compromises to make, for dearly as I love Oregon, should she ever so far forget herself as to allow slavery to exist in her midst, which may God avert, we will quit her borders and flee to a free state.

Such attitudes were hardly unusual for Thurston's time. They emphasize the ease with which gender and racial issues were separable in the minds of most mid-nineteenthcentury politicians.

129. Sept. 22, 1850; Sept. 29, 1850; Nov. 30, 1850; Jan. 5, 1851; Jan. 19, 1851.

130. Jan. 2, 1850 (the mails).

131. Sept. 30, 1849, Nov. 26, 1849; Jan. 2, 1850; Apr. 15, 1850; May 26, 1850; Jun. 9, 1850; Aug. 4, 1850; Sept, 22, 1850.

132. Thurston often wrote informally of his son George Henry and daughter Elizabeth. 
lawyer. ${ }^{133} \mathrm{He}$ was to be cultivated in the "principles of the moral law, ${ }^{134}$ and taught mathematics, literature, science and language. ${ }^{135}$ Thurston's son was to be combative, but ready to conciliate, firm but generous to a fallen enemy. ${ }^{136}$ George Henry, Thurston urged, should be asked to make 'great big speeches' to his mamma or Mr. Hill' 37 'and his mamma must tell him how to do it. '138 Thurston did write that both his children were to be 'deeply read in moral sciences and moral and natural laws, '139 that 'the little daughter, and all that pertains to her, and to her growth, education and fortune in life is as dear to me as that of my boy.'140 But 'my girl [is] to be gentle learned \& good, . . . my boy to be above board, invincible, immoveable. '141 Elizabeth was instructed to "teach Henry politeness, ease of manners, nature, firmness, stern integrity-patriotism-Lissy teach as a girl should be taught.' 142

It is hard to imagine better descriptions of mid-nineteenth century gender roles. Thurston demanded much of both his children. They were to excel, for once getting in the way of it, it will become natural and thus excite them to noble deeds of action when things of a more important nature shall come within the sphere of their duty. ${ }^{143}$ And his wife Elizabeth was the crucial catalyst. She was 'to discharge towards [George Henry] a mother's whole duty. '144 'My dear you have got to shape my posterity, in heavens name give them a form that shall reflect everlasting honor on the artist.'145 Thurston's old essay on female virtue had matured into a fine sense of feminine duty. His wife was exalted not only as a servant to her husband, ${ }^{146}$ but also as a shaper of others, a moulder of the future. Of such sympathies were nineteenth-century male feminists made; exalted separate spheres supported Thurston's liberal image of women.

133. Aug. 17, 1850; Jul. 14. 1850.

134. Jan. 7, 1850. Moral obligation or natural law was discussed in other letters too. E.g., Jul. 14, 1850.

135. Jul. 14, 1850.

136. Jul. 14, 1850; Aug. 17, 1850.

137. Jan. 7, 1850; Feb. 3, 1850; Jul. 7, 1850. Mr. Hill was a family friend with whom Elizabeth Thurston and her two children lived for a time after Samuel went to Congress.

138. Jul. 7, 1850.

139. Jul. 14, 1850.

140. Aug. 17, 1850.

141. Aug. 11, 1850.

142. Dec. 29, 1850.

143. Jan. 1, 1851.

144. Aug. 17, 1850.

145. Dec. 29, 1850.

146. The letters simply never talk of Elizabeth Thurston having only specific duties to her husband. There are adoring comments by Samuel, statements of horror should Elizabeth be unfaithful, and instructions on finances, but no servile commands. 
Thurston's attitudes towards women surfaced one final time before his death in 1851. At the end of his term in Congress, Thurston drafted a letter to his constituents in Oregon. It was a reelection campaign document, which was eventually printed in the Oregon Spectator, a major newspaper in the territory. He had previously written his wife that he planned to run again for Congress. ${ }^{147} \mathrm{He}$ also had 5,000 copies printed of an address to his constituents. The address too was reprinted in the Oregon Spectator. ${ }^{148}$ 'I am not,' Thurston wrote in his letter, 'one of those who would advise her to change her sphere which she appropriately fills, with such effect on the world, for one of strife, and politics, and civil or military commotions, but 1 would throw around her all the protections and safeguards necessary for her safety. They hold the future destiny of the nation in their gentle grasp, and the master spirits of the rising generation are now being moulded by their skill.' There can be little doubt of Thurston's influence over and sympathy with the married women's land grants in the Oregon Donation Act. But this sympathy arose out of a desire to surround wives with sufficient protections so they could act as a moral bastion and source of comfort for their husbands. The homestead exemption features of the House bill were meant to protect men 'against the hands of unfeeling oppression, and saved from the jaws of pinching want. In this way every man will be placed on an eminence, where he can be a man, and his own man; where he can be an independent suffragen, beyond the compelling grasp of the rich lord or politician, and where viewing all measures for himself, he can think, and speak, and vote as a well directed and untrammelled judgment shall direct.' ${ }^{\prime 49}$

147. Letter on June 15, 1850. This letter, one of the longest Thurston wrote to his wife, was a lovely reminisce about Thurston's younger years in Maine. Perhaps he was trying to cushion the blow of the letter's last line. '(confidential),' Thurston wrote. 'I shall be candidate for reelection, Yours truly \&c. Saml R. Thurston.' His wife could hardly have been overjoyed at the news.

148. Nov. 30,1850 . The address was reprinted in four successive issues of the Oregon Spectator, September 26, October 3, October 10 and October 17, 1850.

149. Ibid. Emphasis is in the original. Similar views were expressed by Thurston in his Address to His Constituents in Oregon Territory. The segment of the address in the October 3, 1850 issue of the Oregon Spectator, contains much talk of manual labor as an honorable endeavor, and of homesteads as insurers of men's freedom from the 'clamers of capitalists.' Thurston wrote:

And it has now become to be generally believed, that the safety of the liberties of the people demand that every man, shall, if he will, be put in possession of the means of self-defense. Hence, the doctrine of exemption of estate property from attachment, has become to be the doctrine of the day. The law contemplates leaving sufficiency of means in the hands of every man to enable him, combined with his personal industry, to procure all the necessities of life.

Such attitudes towards homesteads were perfectly compatible with a favorable view of the early married women's property acts. 
Just as Congress debated the wisdom of exempting married women's donation lands from the claims of husbands' creditors, Oregon's courts and legislatures grappled for decades with disputes between wives and family creditors. Although Thurston died before the Oregon Donation Act was implemented, he left behind sugggestions for altering the legislation. While he had acceded to the Senate amendments in order to get the bill through the House during the final weeks of the session, ${ }^{150}$ he was not pleased that the act gave three years rather than five years for future settlers to claim donations and that it failed to exempt wives' donation claims from husbands' creditors. ${ }^{151}$ In addition, a confusing land title picture emerged as the fledgling territorial government passed and repealed land statutes, the General Land Office struggled to open offices in Oregon, and state and federal judges with dramatically different visions of the world battled over the meaning of the Donation Act and related provisions in the Oregon territorial and state codes. ${ }^{152}$ Through all the confusion a steady stream of disputes arose over the relationship between married women owning property and their debtor husbands. From the territorial legislature's adoption in $1852^{153}$ of an act exempting donation claims from claims of husbands through the enactment of the last married women's acts in 1878 and $1880,{ }^{154}$ debates over the rights of creditors played an important part in the development of Oregon's married women's law.

At the time the Oregon Donation Act was adopted married women could not write wills except as provided by an antenuptial agreement. ${ }^{155}$ Only after the territorial legislature passed an act exempting married women's donation claims from their husbands' debts was a married woman permitted to write a

150. If Thurston had tried to alter the bill approved by the Senate, he would certainly have run out of time to get the bill adopted. He therefore took what he could get. See his Letter to the Electors and People of the Territory of Oregon, Thurston Papers, MSS 379, Oregon Historical Society (Nov. 15, 1850) 7.

151. Ibid. 7.

152. Some of the legislative turnabouts are discussed in the text that follows. To contrast the attitudes of some of Oregon's Supreme Court judges with that of federal Judge Matthew P. Deady, compare Brummet v. Weaver, 2. Or. 168 (1866); Rugh v. Ottenheimer, 6 Or. 231 (1877), with Fields v. Squires, 9 F. Cas. 29 (C.C.D. Or. 1868)(No. 4,776); Wythe v. Smith, 30 F. Cas. 771 (C.C.D. Or. 1876)(No. 18,122).

153. An Act to Exempt the Wife's Portion of Lands Donated in Oregon Territory by Act of Congress, Approved September 27, 1850, From the Debts and Liabilities of her Husband (Jan. 20, 1852); General Laws Passed by the Legislative Assembly of Territory of Oregon, at 3d Sess., at Salem Beginning Dec. 1, 1851 (1852) 64.

154. An Act Defining the Rights and Fixing the Liabilities of Married Women, and the Relation Between Husband and Wife (Oct. 21, 1878) in Oregon Session Laws, 10th Sess., (1878) 92; An Act to Establish and Protect the Rights of Married Women (Oct. 21, 1880) in Oregon Session Laws, 1 th Sess., (1880) 6.

155. Section 3, An Act Respecting Wills (Sept. 26, 1849) in Statutes of a General Nature Passed by Legislative Assembly of Territory of Oregon, 2d Sess., Dec. 2, 1850, at Oregon City (1851) 274-75. 
will. But that right extended only to 'real estate held in her own right, subject to any rights which her husband may have as tenant by the curtesy.'156 And tenancy by the curtesy, of course, provided the husband with management and control rights. ${ }^{157}$ Oregon curtesy legislation went even further than usual by providing husbands with life estates in their wives' real estate regardless of whether children had been born of the marriage. Unless the language of the Donation Act itself was read to provide married women with the right to manage their claims, the exemption legislation, like the early married women's acts adopted in other states, acted only as a debtor protection measure. More confusion was created when, in 1854, the territorial legislature adopted an act repealing all but a few statutes adopted before the fifth session of the territorial legislature. ${ }^{158}$ This act, which arose because the chaotic politics of the territory had produced arguments over where the legislature should sit and disputes over what laws were operative, had the effect of repealing the exemption act, but not the curtesy provisions. ${ }^{159}$ Not until the adoption of the Oregon state constitution in 1859 was a debtor exemption provision firmly embedded in the state's coverture laws. ${ }^{160}$

At the end of the Oregon Territory's first decade, therefore, married women were in something of an anomalous position. Although the Donation Act had been amended to provide protections for widows of deceased male settlers and emigrants, ${ }^{161}$ and married women were coming to

156. Section 3, An Act Relating to Wills (Dec. 15, 1853) in Statutes of Oregon, at Session Beginning Dec. 5, 1853 (1854) 354-55.

157. Section 30, An Act Relating to Estates in Dower, by Curtesy and General Provisions, Concerning Real Estates (Jan. 16, 1854) in Statutes of Oregon, at Session Beginning Dec. 5, 1853 (1854) 373.

158. An Act to Repeal All Acts Heretofore Passed, With Certain Exceptions (Jan. 30, 1854) in Statutes of Oregon, at Session Beginning Dec. 5, 1853 (1854) 505.

159. See James K. Kelley, 'History of the Preparation of the First Code of Oregon,' Oregon Historical Quarterly 4 (1903) 185.

160. Article XV, Section V, of the Oregon Constitution of 1859, provided:

The property and pecuniary rights of every married woman, at the time of marriage, or afterwards, acquired by gift, devise, or inheritance, shall not be subject to the debts or contracts of the husband; and laws shall be passed providing for the registration of the wife's separate property.

161. At the urging of the territorial legislature and the Surveyor General, Congress amended the Donation Act three times to insure that widows of male claimants and males dying en route to Oregon could make donation claims, to permit donation claimants to pay for their land and short circuit the four-year occupancy requirements and to extend the time period in which persons could file claims. The history of the widow's provisions is much like that of earlier federal land bills which had to be amended to benefit the spouse of the deceased claimants. One other interesting problem surfaced involving widows. After some controversy between the lower courts and the land bureaucracy, the Supreme Court eventually held that married women's claims were derivative of their husbands. Thus, the spouses of men dying before completing the four years of occupancy risked losing their claims. Vance v. Burbank, 101 U.S. 514 (1879). 
own substantial amounts of real estate, ${ }^{162}$ the Donation Act had little immediate impact on the structure of coverture law in Oregon. The narrowly drawn married women's act exempting land from husband's creditors was probably generated by the Donation Act debates, but it was lost in the repealer statute of 1854 . Traditional curtesy rights of husbands continued to exist. Although chancery actions were recognized in the territory, ${ }^{163}$ and private bills in equity-like situations were adopted from time to time, 164 married women's separate estates were still subject to narrow rules of judicial construction. Not until the debates over the drafting of the state constitution did the Donation Act take on significance as a symbol, and perhaps even a contributing cause, to the development of a married women's law reform movement in Oregon. ${ }^{165}$

162. It is not clear if the Oregon Donation Act had an impact on the relative wealth of men and women in the state. What happened to all the land owned by women in Oregon as the nineteenth century progressed is not known. Until land title chains are studied in some detail, we are left with a hypothesis that some lasting cultural impact may have occurred as a result of the Donation Act. There is some indication that even this hypothesis may be false. Davenport, 'An Object Lesson in Paternalism,' Oregon Historical Quarterly 4 (1903) 33. Davenport surveyed 100 square miles on the east side of the Willamette Valley in Marion County and found that:

[S]ixty-six per cent of donation claims have passed out of the possession of the donees and their descendants, another fifteen per cent are mortgaged for all they are worth, and for practical purposes may be considered as lost to them. Not more than fifteen per cent of the whole have been ordinarily successful in holding and improving a part of their possessions and are now free from debt. Only five of all of them have increased their holdings and are thrifty.

Ibid. 50-51. Davenport appears not to have studied how persons selling their land used the money received; nor did he focus on women's holdings. His study also reflects the late nineteenth-century biases against debt and fails to analyze the impact of the one-third of the claims still held by the original donee families. But it is certainly possible that many of the claims obtained by women were transferred to men over the years.

163. See An Act to Regulate Proceedings in Suits in Equity, Ore. Terr. Stat., 5th Sess. (Jan. 23, 1854). See also Pittman v. Pittman, 4 Ore. 298 (1872), where Emily Pittman was denied relief in a court of law for the use by her husband of a $\$ 1,000$ separate estate trust fund. She was told to seek a remedy in an equity court.

164. See An Act to Authorize Campbell E. Cristman and Lucinda Cristman to Make a Marriage Settlment of Their Property, Ore. Terr. Stat., 8th Sess. (Jan. 12, 1857) (permitted a postnuptial marriage settlement). Divorces were also granted, some of which reinstated property rights, permitted resumed use of maiden names, granted child custody to women and confirmed divorce settlement agreements. See Act to Divorce Dillard Martin and Miriam Martin (Jan. 17, 1859); An Act to Divorce Nancy Judson and Lewis H. Judson (Jan. 19, 1859); An Act to Divorce Susan Tary and William Tary (Jan. 22, 1859); An Act to Divorce Hessey Williams (Jan. 19, 1859); An Act to Divorce Mary Culbertson From Her Husband, Wm. A. Culbertson (Jan. 20, 1859); An Act to Divorce Sarah Torrence (Jan. 22, 1859).

165. Newspaper reports of the proceedings of the Constitutional Convention of 1857 have been pulled together in C.H. Carey, ed., The Oregon Constitution and Proceedings and Debates of the Constitutional Convention of 1857 (1926). Some discussion of debtor protection issues and the Oregon Donation Act occurred. Ibid. 367-69. 
These conflicts in Oregon were almost inevitable, given the outcome of the Oregon Donation Act debates in Congress. The adoption of married women's acts all over the country, along with Thurston's dying request to his colleagues to adopt a debtor exemption act, guaranteed that Congress's failure to adopt Sackett's House amendment to the Donation Act would be a subject of continuing debate in Oregon. As was typical of so much federal land legislation, congressional compromises or ineptitude left many blanks and ambiguities for local government or national bureaucracies to resolve. ${ }^{166}$

But even had Congress decided to exempt donation claims from creditors of husbands, many disputes would have been left to decide. If, as the early married women's acts provided, married women's separate estates were not available to creditors of husbands, certain disputes were preordained. First, insecurity over which assets were to be denominated as separate and which as subject to the traditional control of husbands, was unavoidable under the new statutes. Since the acts were imprecise as to whether trustees were required to hold separate property, the language necessary to establish the estate, the ability of married women to manage or dispose of their separate property, and the extent to which third parties dealing with a married couple would be deemed constructively aware of the existence of separate estates, creditors of the family unit were subject to a significant amount of insecurity involving separately held property. Second, the exemption of only married women's property created a strange set of incentives. Presuming a husband willing to vest control of valuable assets in his spouse, the acts created a strong impulse to 'bury' property in a wife to protect it from risk and creditors. To the degree that insecurity over the meaning of the new separate estate existed, it was also possible for unscrupulous, or even well intentioned, men to use their wives' property as enticement for deals, only to plead the debtor exemption provisions if the deals later soured. It was predictable that these sorts of problems would require further legislative intervention. A variety of responses were possible, depending upon the degree of legislative sympathy with creditors or debtors. But in all such responses, one would expect the legislature to increase certainty as to which assets were available to creditors of the family.

One of the most interesting features of the development of married women's property law was the gradual development of a full-fledged property device. Men's estates had long been surrounded with certain automatic appendages. The creation of a fee simple carried with it rights of transfer, devise and management. The need to increase creditors' security over the meaning of a separate estate meant that similar appendages had to be developed for women. That, of course, is exactly what married women's acts did in the second half of the century. Women gained transfer, management and devising rights, slowly obtaining parity, at least in legal

166. There are many examples of ineptly drafted or ambiguously worded land grant statutes. One series of statutes which contained inexplicable differences over time was of those dealing with preemption. Some of the multitude of variations in these statutes is reported supra note 28 . 
theory, with male property owners. Of necessity, these developments would lead to a slow loss of special status for property owned by married women. It would, for example, become more rather than less available to creditors of the family, unless the general exemption statutes applicable to men were significantly modified. It is this slow movement from special status to equal treatment that marks both the general content of married women's acts in the second half of the nineteenth century and the ability of creditors to rely upon married women's assets as viable security. 167 The Donation Act debates in Congress marked the beginning of this developmental process for Oregon.

167. See Chused, 'Married Women's Property Law,' supra note 1, 1409-12. 